$\mathrm{A} \int_{\cos } \mathrm{H}$

Article history :

Received : 21.02.2015

Revised : 06.04.2015

Accepted : 10.05.2015

Members of the Research Forum

Associated Authors:

${ }^{1}$ Horticultural Research Station,

Tamil Nadu Agricultural University, OOTY (T.N.) INDIA

Author for correspondence :

M. ANAND

Horticultural Research Station,

Tamil Nadu Agricultural University,

OOTY (T.N.) INDIA

Email : anandhort@yahoo.com
THEASIAN JOURNAL OF HORTICULTURE

Volume 10 | Issue 1 | June, 2015 | 105-112

Visit us -www.researchjournal.co.in

\title{
Studies on per se performance and combining ability in tomato under Coimbatore condition
}

\section{ANAND AND A. SANKARI ${ }^{1}$}

ABSTRACT : A study on diallel crossing involving nine parents, were taken up and crosses were effected in all possible combinations. Thus, a total of $72 \mathrm{~F}_{1}$ crosses and their nine parents were evaluated for various quantitative and qualitative characters. Per se performance of the parents for different traits revealed that among nine parents involved, $\mathrm{P}_{5}$ showed superiority for yield per plant. $\mathrm{P}_{6}$ was superior for single fruit weight and $\mathrm{P}_{2}$ for days to fifty per cent flowering and $\mathrm{P}_{2}$ and $\mathrm{P}_{3}$ showed highest plant height. In case of hybrids tested the cross $\mathrm{P}_{3} \times \mathrm{P}_{6}$ was superior for plant height, days to fifty per cent flowering and yield per plant. The combinations $\mathrm{P}_{6} \times \mathrm{P}_{4}$ and $\mathrm{P}_{6} \times \mathrm{P}_{8}$ exhibited highest single fruit weight. The magnitude of GCA variances for all the characters studied were higher than their corresponding SCA variances in all 72 crosses, suggesting that all the 18 traits studied were controlled by additive gene action. Analyzing the GCA effects of parents for various traits revealed that $\mathrm{P}_{2}, \mathrm{P}_{3}$ and $\mathrm{P}_{5}$ were the best general combiners for almost all the traits. The parent $\mathrm{P}_{1}$, followed by parent $\mathrm{P}_{3}$ had higher per se with higher GCA effects for most of the economic traits studied. Hence, the parents $\mathrm{P}_{1}$ and $\mathrm{P}_{3}$ could be exploited in further breeding programmes for over all tomato crop improvement. The next best choice would be $\mathrm{P}_{4}$ when the breeders aim is primarily to increase the fruit yield and quality characters. The hybrid cross $\mathrm{P}_{2} \times \mathrm{P}_{3}$ exhibited more number of fruiting clusters per plant and highest single fruit weight was noticed in $\mathrm{P}_{1} \times \mathrm{P}_{4}$ and $\mathrm{P}_{1} \times \mathrm{P}_{5}$. Highest yield per plant was recorded in $\mathrm{P}_{2} \times \mathrm{P}_{3}$.

KEY WORDS : Performance, Combining ability, Tomato

HOW TO CITE THIS ARTICLE : Anand, M. and Sankari, A. (2015). Studies on per se performance and combining ability in tomato under Coimbatore condition. Asian J. Hort., 10(1) : 105-112. 